\title{
Association of vitamin D and cardiovascular health
}

\author{
Hridaya Bibhu Ghimire, ${ }^{1}$ Chandra Mani Adhikari ${ }^{2}$
}

\author{
${ }^{1}$ Department of Cardiology, Jeevan Bikas Public Health Centre, Katahari, Morang, Nepal. \\ ${ }^{2}$ Department of Cardiology, Shahid Gangalal National Heart Centre, Bansbari, Kathmandu, Nepal.
}

Corresponding Author: Hridaya Bibhu Ghimire

Jeevan Bikas Samaj, Katahari, Morang, Nepal

Email: hbghimire@hotmail.com

\begin{abstract}
Vitamin D insufficiency or deficiency is highly prevalent due to limited sun exposure especially in urban and elderly population. Vitamin D is now increasingly recognized as a hormone responsible for numerous physiologic functions in different cells and tissues of the human body including heart. Vitamin D has been shown to be linked with hypertension, acute coronary syndrome, heart failure, and atrial fibrillation. This review briefly overviews the relationship between vitamin D deficiency, its supplementation and outcome in cardiovascular health.
\end{abstract}

DOI: http://dx.doi.org/10.3126/njh.v15i1.19706

\section{Introduction}

Vitamin D is available in its two major forms: vitamin D2 (ergocalciferol) and vitamin D3 (cholecalciferol). ${ }^{1}$ Few foods naturally contain or are fortified with vitamin $\mathrm{D}$ whereas ultraviolet B irradiation to the skin converts 7-dehydrocholesterol to pre-vitamin D3, and is one of the important sources of vitamin D3 in human body. Vitamin D from skin and food is metabolized in the liver to form 25-hydroxyvitamin D [25(OH) $\mathrm{D}$; D represents $\mathrm{D} 2$ or D3], which is used to determine patient's vitamin D status. ${ }^{2}$ However, $25(\mathrm{OH}) \mathrm{D}$ is inactive and its further hydroxylation in the kidney is required to produce active form 1,25-dihydroxyvitamin $\mathrm{D}[1,25(\mathrm{OH}) 2 \mathrm{D}$, calcitriol].1,3 Many experts define vitamin D deficiency, insufficiency, and sufficiency as levels of $<20 \mathrm{ng} / \mathrm{ml}$ ( $50 \mathrm{nmol} / \mathrm{L}), 20$ to $30 \mathrm{ng} / \mathrm{ml}$ (50 to 75 $\mathrm{nmol} / \mathrm{L})$, and $>30 \mathrm{ng} / \mathrm{mL}(75 \mathrm{nmol} / \mathrm{L})$, respectively. ${ }^{1,-6}$

\section{Prevalence of vitamin D deficiency}

It has been estimated that about a billion of world's population are either vitamin $\mathrm{D}$ deficient or insufficient. ${ }^{1}$ Irrespective of age group, ethnic community and latitude of study populations, $13.0 \%$ of the 55,844 European people had serum $25(\mathrm{OH}) \mathrm{D}$ levels $<30 \mathrm{nmol} / \mathrm{L}$ on average in a year and when the level was $<50 \mathrm{nmol} / \mathrm{L}(20 \mathrm{ng} / \mathrm{ml})$, the prevalence was $40.4 \%$. A national sample of 11,247 Australian adults showed that $31 \%$ (22\% men, 39\% women) had $25(\mathrm{OH}) \mathrm{D}<50 \mathrm{nmol} / \mathrm{L}(20 \mathrm{ng} /$ $\mathrm{ml})$ whereas $73 \%$ had levels $<30 \mathrm{ng} / \mathrm{ml} .{ }^{8}$ The National Health and Nutrition Examination Survey 2005 to 2006 data of 4495 adult participants showed that overall prevalence of $25(\mathrm{OH}) \mathrm{D}$ $\leq 20 \mathrm{ng} / \mathrm{ml}(50 \mathrm{nmol} / \mathrm{L})$ was $41.6 \%$, with the highest rate seen in blacks $(82.1 \%)$, followed by Hispanics $(69.2 \%) .{ }^{9}$ The prevalence of vitamin D deficiency was about $70 \%$ or higher in South Asia whereas varied from 6 to $70 \%$ in Southeast Asia, when 25(OH)D level $<20 \mathrm{ng} / \mathrm{ml}$ was used as cut-off. ${ }^{10}$

\section{Risk factors for vitamin D deficiency}

Risk factors for vitamin D deficiency or insufficiency are old age, ${ }^{11}$ dark skin pigmentation, ${ }^{12}$ smoking, ${ }^{13}$ obesity, ${ }^{14}$ kidney disease,,$^{15}$ chronic liver disease, ${ }^{16}$ and intestinal malabsorption syndromes (including, celiac disease, cystic fibrosis, short bowel syndrome, inflammatory bowel disease) ${ }^{17}$ In addition to this, vitamin $\mathrm{D}$ deficiency is also associated with environmental variables such as air pollution, ${ }^{18}$ winter season, ${ }^{19}$ decreased exposure to sun light (for example indoor worker and shift worker) ${ }^{20}$ and in people with decreased outdoor physical activity, frailty and institutionalized elderly. ${ }^{21}$

\section{Pathophysiology of vitamin D deficiency and cardiovascular disease}

Vitamin D receptor proteins have been identified in different human tissues ${ }^{22}$ including heart. ${ }^{23} 1,25(\mathrm{OH}) 2 \mathrm{D}$ directly regulates the proliferation of cardiac myocyte and induces the myocyte hypertrophy. ${ }^{24}$ Different studies suggest that vitamin $D$ decreases renin-angiotensin-aldosterone activity. ${ }^{25}$ The cardiac hypertrophy seen in vitamin D receptor knockout mice is due to the activation of both the systemic and cardiac renin-angiotensin system (RAS) suggesting that $1,25(\mathrm{OH}) 2 \mathrm{D}$ regulates the cardiac function, at least in part, through the RAS. ${ }^{26}$ The secondary hyperparathyroidism and altered level of vitamin $\mathrm{D}$ found in chronic renal failure patient contribute to cardiovascular pathology and also to the excess mortality from cardiovascular causes found in these uremic group of patients. ${ }^{27}$ A strong association was seen between vitamin $\mathrm{D}$ deficiency and slow coronary flow phenomenon, endothelial dysfunction and subclinical atherosclerosis, during coronary angiography in patients with normal or near-normal coronary arteries. ${ }^{28}$ Administration of activated forms of vitamin D $(1,25[\mathrm{OH}] 2 \mathrm{D}$ or analogs) to patients with end stage renal disease and secondary hyperparathyroidism results in regression in myocardial hypertrophy. ${ }^{29}$

\section{Vitamin D and hypertension}

Meta-analysis done from randomized controlled trials of oral vitamin $\mathrm{D}$ supplementation found that supplementation of vitamin D significantly reduced systolic blood pressure (BP) by

@Nepalese Heart Journal. Nepalese Heart Journal retains copyright and work is simultaneously licensed under Creative Commons Attribution License CC - BY 4.0 that allows others to share the work with an acknowledgement of the work's authorship and initial publication in this journal. 
$2.44 \mathrm{mmHg}$, but did not decrease the diastolic BP. ${ }^{30} \mathrm{~A}$ Mendelian randomization study to meta-analyse 146,581 participants found that each $10 \%$ increase in genetically instrumented $25(\mathrm{OH}) \mathrm{D}$ was associated with decrease in diastolic $\mathrm{BP}(-0.29 \mathrm{mmHg}, \mathrm{p}=0.01)$, systolic $\mathrm{BP}(-0.37 \mathrm{mmHg}, \mathrm{p}=0.052)$, and an $8.1 \%$ decreased odds of hypertension $(\mathrm{p}=0.002) .{ }^{31}$ Randomized controlled trials in participants with mean baseline BP $>140 / 90 \mathrm{mmHg}$ showed a non-significant reduction in systolic $\mathrm{BP}$ and a small significant reduction in diastolic $\mathrm{BP}(3.1 \mathrm{mmHg})$, whereas no significant reduction in $\mathrm{BP}$ was seen in patients who were normotensive at baseline. ${ }^{32}$ Role of vitamin $\mathrm{D}$ or ultraviolet $\mathrm{B}$ radiation in $\mathrm{BP}$ regulation done in 10 trials found no significant effect of vitamin $\mathrm{D}$ on BP. ${ }^{33}$ However, when limiting the analysis to studies that used higher doses of vitamin D supplementation (at least 1,000 IU/day), a small but statistically significant effect was seen. No significant BP-lowering effect of vitamin D supplements was seen in a meta-analysis which evaluated cardiovascular outcomes. The study stated that there was significant heterogeneity associated with this analysis. ${ }^{34}$ Genetically determined variants were associated with low $25(\mathrm{OH}) \mathrm{D}$ and such population had higher blood pressure. ${ }^{35}$ Meta-analysis of 16 randomized clinical trials revealed that there is no significant reduction of systolic and diastolic BP with vitamin D supplementation. ${ }^{36}$ Subgroup analysis showed a significant reduction in diastolic $\mathrm{BP}$ in participants who had cardiometabolic disease.

\section{Vitamin D and acute coronary syndrome}

In the Health Professionals Followup Study of 18,225 men, lower levels of vitamin D were linked with increased risk of acute myocardial infarction (MI), even after controlling the risk factors known to be associated with coronary artery disease. People with normal vitamin D levels (> $30 \mathrm{ng} / \mathrm{mL}$ ) were found to have half the risk of acute $\mathrm{MI}$ at 10 -year follow-up compared to those with deficient vitamin D level. ${ }^{37}$ A multicenter cohort study was done in United States with acute coronary syndrome and found that $96 \%$ of these patients at hospital presentation had vitamin D levels $<30 \mathrm{ng} / \mathrm{mL} .{ }^{38}$ Vitamin D deficiency was independently associated with more severe acute coronary syndrome and was a predictor of more extensive coronary lesions in patients with type 2 diabetes mellitus. ${ }^{39}$ In patients with ST elevated MI and non-ST elevated MI, serum 25(OH)D levels were significantly low and that low serum $25(\mathrm{OH}) \mathrm{D}$ were significantly associated with severity and extent of coronary artery disease as assessed by SYNTAX score. ${ }^{40} \mathrm{~A}$ metaanalysis showed that an adjusted overall relative risk of 1.52 for total cardiovascular events, 1.42 for cardiovascular mortality and 1.38 for coronary heart disease when compared with lowest to highest categories of baseline circulating vitamin D concentration ranging from 20 to 60 $\mathrm{nmol} / \mathrm{L} .{ }^{41}$ When parathyroid hormone levels were high, increased level of $25(\mathrm{OH}) \mathrm{D}$ was associated with a lower risk of coronary heart disease,whereas no association was seen for participants with low level of parathyroid hormone. ${ }^{42}$ Low vitamin D in acute coronary syndrome is linked with longterm major adverse cardiovascular events, which includes rehospitalization for acute decompensated heart failure or for successive acute coronary syndrome.Patients with acute myocardial infarction and $25(\mathrm{OH})$ D3 level more than $7.3 \mathrm{ng} / \mathrm{ml}$ were found to have approximately $40 \%$ lower risk for major adverse cardiac events. ${ }^{43}$

\section{Vitamin $\mathrm{D}$ and heart failure}

Vitamin D deficiency is highly prevalent in the elderly population, and there has been strong association between vitamin $\mathrm{D}$ deficiency and increased risk of heart failure in the elderly. ${ }^{44}$ Supplementation of vitamin D decreased the serum levels of parathyroid hormone and inflammatory mediators like tumor necrosis factor- $\alpha$ and C-reactive protein in heart failure patients whereas no beneficial effects were seen in terms of left ventricular ejection fraction, $\mathrm{N}$-terminal pro-B-type natriuretic peptide (BNP), and six minute walk distance. ${ }^{45}$ Vitamin D supplementation decreased the severity of heart failure as seen by reduction in serum pro-BNP levels and increase in six minutes' walk distance, ${ }^{46}$ whereas no significant difference in six minute walk distance was seen in heart failure patients with vitamin D supplementation. ${ }^{47}$ Low level of vitamin D was associated with various major cardiovascular risk factors and cardiac structural changes including impaired systolic and diastolic function. ${ }^{48}$ Low vitamin $\mathrm{D}$ level has been associated with risk of heart failure, ventricular remodelling, and clinical outcomes in heart failure, including mortality. However, till date there are inadequate data to recommend routine assessment or supplementation of vitamin $\mathrm{D}$ for the prevention or treatment of chronic heart failure. ${ }^{49}$

\section{Vitamin D and atrial fibrillation}

Vitamin D deficiency was associated with new-onset atrial fibrillation (AF) in hypertensive patients. ${ }^{50}$ Vitamin D level was not linked with $\mathrm{AF}$ in any of the three multivariate models tested (models adjusted for socio-demographic factors and life-style factors). ${ }^{51}$ Vitamin $\mathrm{D}$ deficiency was related to non valvular $\mathrm{AF}$ but not with valvular $\mathrm{AF}^{52}$ Studies suggest that there may be an association between vitamin D deficiency and $\mathrm{AF}$, incomparable study designs and methodological limitations hinder interpretation for definite evidence ${ }^{53}$ Incidence of post operative atrial fibrillation after coronary artery bypass surgery was significantly higher in patients with vitamin $\mathrm{D}$ deficiency or insufficiency than the patients with normal vitamin D level. ${ }^{54}$

\section{Vitamin D level and cardiovascular disease outcome}

In a 1739 Framingham offspring study participants, people with $25(\mathrm{OH}) \mathrm{D}<15 \mathrm{ng} / \mathrm{ml}$ had a multivariate-adjusted hazard ratio of 1.62 (95\% confidence interval 1.11 to 2.36 ) for incident cardiovascular events in comparison to those with $25(\mathrm{OH})$ $\mathrm{D} \geq 15 \mathrm{ng} / \mathrm{ml} .{ }^{55}$ The effect was evident in participants with hypertension but not in those without hypertension. In a metaanalysis of 26916 participants with median follow-up time of 10.5 years, compared to $25(\mathrm{OH}) \mathrm{D} 75-99.99 \mathrm{nmol} / \mathrm{L}$, adjusted hazard ratio of death from cardiovascular causes $(95 \%$ confidence interval) for 25(OH)D 50-74.99, 40-49.99, 30-39.99, and <30 $\mathrm{nmol} / \mathrm{L}$ were 1.37 (1.12-1.67), 1.65 (1.39-1.97), 1.61 (1.46-1.77), and $2.21(1.50-3.26)$ respectively. ${ }^{56}$

\section{Vitamin D supplementation and cardiovascular disease outcome}

Even though vitamin $\mathrm{D}$ has been shown to be associated with cardiac disease but supplementation of vitamin D does not show convincing results. Vitamin D supplementation did not show clear evidence of benefits for preventing heart failure or influencing its clinical course. ${ }^{57}$ Recent review from randomized controlled trials demonstrated that supplementation of vitamin $\mathrm{D}$ is ineffective in improving cardiovascular health among diverse patient populations, including those with or without vitamin D deficiency. ${ }^{58}$ In the absence of specifically designed long-term study of vitamin D supplementation on cardiovascular effects, it is difficult to reject that supplementation of vitamin $\mathrm{D}$ has no cardiovascular benefit. ${ }^{59}$ Some favourable reports were also seen in vitamin D supplementation. Supplementation of vitamin D might protect against heart failure in elderly but does not seem to protect against myocardial infarction or stroke. ${ }^{60}$ There are weak signals of benefit of vitamin D supplementation in cardiac failure while vitamin $\mathrm{D}$ is found to be ineffective in lowering blood pressure. Although low vitamin D levels are associated with coronary artery disease, atrial fibrillation, peripheral vascular disease, and stroke, there is no significant benefit after vitamin D supplementation. ${ }^{61}$ 


\section{Summary}

Patients with cardiovascular disease, especially those with heart failure that is severe enough, usually spend less time outdoor thereby do have minimal exposure to sun light. Cardiovascular disease affected patients are generally elderly. Both advanced age and decreased sun exposure are the risk factors for vitamin $\mathrm{D}$ insufficiency or deficiency. It has been found that there are associations of vitamin D deficiency with cardiovascular disease but to date, the review of vitamin D supplementation on cardiovascular patients has not shown convincing significant outcomes. Hence, vitamin D deficiency in these patients would only be because of their frailty and limited sun exposure. Due to the occurrence of vitamin $\mathrm{D}$ receptors in human heart tissue and the effect of vitamin D on structural changes of the heart, it cannot be neglected that vitamin $\mathrm{D}$ does not possess any role in cardiovascular health. It is therefore necessary to conduct large placebo (such as time spend indoor and outdoor with or without sun exposure) controlled randomised trials so as to give any definite conclusions.

\section{Conclusions}

The studies done till date show mix results about the link of vitamin D deficiency with cardiovascular health. More large randomised placebo-controlled trials may be needed before any recommendations.

\section{References:}

1. Holick MF. Vitamin D deficiency. N Engl J Med 2007; 357 : 266-81. https://doi.org/10.1056/NEJMra070553

2. Holick MF. Vitamin D status: measurement, interpretation, and clinical application. Ann Epidemiol. 2009;19(2):73-8. https://doi.org/10.1016/j.annepidem.2007.12.001

3. Mosekilde L. Vitamin D requirement and setting recommendation levels: long-term perspectives. Nutr Rev 2008; 66: S170-7. https://doi.org/10.1111/j.17534887.2008.00103.x

4. Bischoff-Ferrari HA, Giovannucci E, Willett WC, et al. Estimation of optimal serum concentrations of 25-hydroxyvitamin D for multiple health outcomes. Am J ClinNutr. 2006;84(1):18-28. https://doi.org/10.1093/ ajen/84.1.18

5. Holick MF, Binkley NC, Bischoff-Ferrari HA, et al. Evaluation, treatment, and prevention of vitamin D deficiency: an Endocrine society clinical practice guideline. J Clin Endocinol Metab. 2011;96(7):1911-30. https://doi. org/10.1210/jc.2011-0385

6. Rizzoli R, Boonen S, Brandi ML, et al. Vitamin D supplementation in elderly or postmenopausal women: a 2013 update of the 2008 recommendations from the European Society for Clinical and Economic Aspects of Osteoporosis and Osteoarthritis (ESCEO). Curr Med Res Opin. 2013;29(4):305-13. https://doi.org/10.1185/0300799 5.2013 .766162

7. Cashman KD, Dowling KG, Skrabakova Z, et al. Vitamin D deficiency in Europe: pandemic? Am J Clin Nutr. 2016;103(4):1033-44. https://doi.org/10.3945/ ajcn.115.120873

8. Daly RM, Gagnon C, Lu ZX, et al. Prevalence of vitamin $\mathrm{D}$ deficiency and its determinants in Australian adults aged 25 years and older: a national, population-based study. Clin Endocrinol (Oxf). 2012;77(1):26-35. https://doi. org/10.1111/j.1365-2265.2011.04320.x

9. Forrest KY, Stuhldreher WL. Prevalence and correlates of vitamin D deficiency in US adults. Nutr Res. 2011;31(1):48-
54. https://doi.org/10.1016/j.nutres.2010.12.001

10. Nimitphong H, Holick MF. Vitamin D status and sun exposure in southeast Asia. Dermatoendocrinol. 2013;5(1):34-37. https://doi.org/10.4161/derm.24054

11. Boucher BJ. The problems of vitamin D insufficiency in older people. Aging Dis. 2012;3(4):313-29.

12. Harris SS. Vitamin D and African Americans. J Nutr. 2006; 136(4):1126-9. https://doi.org/10.1093/jn/136.4.1126

13. Kassi EN, Stavropoulos S, Kokkoris P, et al. Smoking is a significant determinant of low serum vitamin $\mathrm{D}$ in young and middle-aged healthy males. Hormones (Athens). 2015;14(2):245-50.

14. Wortsman J, Matsuoka LY, Chen TC, et al. Decreased bioavailability of vitamin $\mathrm{D}$ in obesity. Am J ClinNutr. 2000; 72(3):690-3. https://doi.org/10.1093/ajcn/72.3.690

15. Al-Badr W, Martin KJ. Vitamin D and kidney disease. Clin J Am Soc Nephrol. 2008;3(5):1555-60. https://doi. org/10.2215/CJN.01150308

16. Iruzubieta $\mathrm{P}$, Teran $\mathrm{A}$, Crespo J, et al. Vitamin D deficiency in chronic liver disease. World J Hepatol. 2014;6(12):90115. https://doi.org/10.4254/wjh.v6.i12.901

17. Margulies SL, Kurian D, Elliott MS, et al. Vitamin D deficiency in patients with intestinal malabsorption syndromes-think in and outside the gut. J Dig Dis. 2015;16(11):617-33. https://doi.org/10.1111/17512980.12283

18. Hosseinpanah F, Pour SH, Heibatollahi M, et al. Effects of air pollution on vitamin $\mathrm{D}$ status in healthy women: a cross sectional study. BMC Public Health. 2010;10:519. https:// doi.org/10.1186/1471-2458-10-519

19. TangprichaV, Pearce EN, Chen TC, et al. Vitamin D insufficiency among free-living healthy young adults. Am J Med. 2002;112(8):659-62. https://doi.org/10.1016/S00029343(02)01091-4

20. Sowah D, Fan X, Dennett L, et al. Vitamin D levels and deficiency with different occupations: a systematic review. BMC Public Health. 2017;17:519. https://doi.org/10.1186/ s12889-017-4436-z

21. Papapetrou PD, Triantafyllopoulou M, Korakovouni A. Severe vitamin D deficiency in the institutionalized elderly. J Endocrinol Invest. 2008;31(9):784-7. https://doi. org/10.1007/BF03349258

22. Wang Y, Zhu J, DeLuca HF. Where is the vitamin D receptor? Arch Biochem Biophys. 2012;523(1):123-33. https://doi.org/10.1016/j.abb.2012.04.001

23. O'Connell TD, Simpson RU. Immunochemical identification of the 1,25-dihdoxyvitamin D3 receptor protein in human heart. Cell Biol Int. 1996;20(9):621-4. https://doi.org/10.1006/cbir.1996.0081

24. O'Connell TD, Berry JE, Jarvis AK et al.1,25dihydroxyvitamin D3 regulation of cardiac myocyte proliferation and hypertrophy.AmJ Physiol. 1997;272:17518. https://doi.org/10.1152/ajpheart.1997.272.4.H1751

25. Tamez H, Kalim S, Thadhani RI. Does vitamin D modulate blood pressure? Curr Opin Nephrol Hypertens. 2013;22(2):204-9. https://doi.org/10.1097/ MNH.0b013e32835d919b

26. Xiang W, Kong J, Chen S, et al. Cardiac hypertrophy in vitamin $\mathrm{D}$ receptor knockout mice: role of systemic and cardiac renin-angiotensin systems. Am J Physiol Endocrinol Metab. 2005;288(1):E125-32. https://doi.org/10.1152/ ajpendo.00224.2004

27. Rostand SG, Drueke TB. Parathyroid hormone, vitamin D, and cardiovascular disease in chronic renal failure. Kidney Int. 1999;56(2):383-92. https://doi.org/10.1046/j.1523$1755.1999 .00575 . \mathrm{x}$ 
28. Oz F, Cizgici AY, Oflaz H, et al. Impact of vitamin D insufficiency on the epicardial coronary flow velocity and endothelial function. Coron Artery Dis. 2013;24(5):392-7. https://doi.org/10.1097/MCA.0b013e328362b2c8

29. Park CW, Oh YS, Shin YS, et al. Intravenous calcitriol regresses myocardial hypertrophy in hemodialysis patients with secondary hyperparathyroidism. Am J Kidney Dis. 1999;33(1):73-81. https://doi.org/10.1016/S02726386(99)70260-X

30. Wu SH, Ho SC, Zhong L. Effects of vitamin D supplementation on blood pressure. South Med J. 2010; 103(8):729-37. https://doi.org/10.1097/ SMJ.0b013e3181e6d389

31. Vimaleswaran KS, Cavadino A, Berry DJ, et al. Association of vitamin D status with arterial blood pressure and hypertension risk: a mendelian randomisation study. Lancet Diabetes Endocrinol. 2014;2(9):719-29. https://doi. org/10.1016/S2213-8587(14)70113-5

32. Witham MD, Nadir MA, Struthers AD. Effect of vitamin D on blood pressure: a systematic review and meta-analysis. J Hypertens. 2009; 27(10):1948-54. https://doi.org/10.1097/ HJH.0b013e32832f075b

33. Pittas AG, Chung M, Trikalinos T, et al. Systematic review: Vitamin D and cardiometabolic outcomes. Ann Intern Med. 2010; 152(5):307-14. https://doi.org/10.7326/00034819-152-5-201003020-00009

34. Elamin MB, Abu Elnour NO, Elamin KB, et al. Vitamin $\mathrm{D}$ and cardiovascular outcomes: a systematic review and meta-analysis. J Clin Endocrinol Metab. 2011; 96(7):193142. https://doi.org/10.1210/jc.2011-0398

35. Afzal S, Nordestqaard BG. Vitamin D, hypertension, and ischemic stroke in 116655 individuals from the general population: a genetic study. Hypertension. 2017.pii: HYPERTENSIONAHA.117.09411.

36. KunutsorSK, Burgess S, Munroe PB, et al. Vitamin D and high blood pressure: causal association or epiphenomenon? EurJ Epidemiol.2014; 29(1):1-14. https://doi.org/10.1007/ s10654-013-9874-z

37. Giovannucci E, Liu Y, Hollis BW, et al. 25-hydroxyvitamin $\mathrm{D}$ and risk of myocardial infarction in men: a prospective study. Arch Intern Med. 2008; 168(11): 1174-80. https:// doi.org/10.1001/archinte.168.11.1174

38. Lee JH, Gadi R, Spertus JA, et al. Prevalence of vitamin D deficiency in patients with acute myocardial infarction. Am J Cardiol 2011; 107(11): 1636-8. https://doi.org/10.1016/j. amjcard.2011.01.048

39. Gondim F, Caribe A, Vasconcelos KF, et al. Vitamin D deficiency is associated with severity of acute coronary syndrome in patients with type 2 diabetes mellitus and high rates of sun exposure. Clin Med Insights Endocrinol Diabetes. 2016;9:37-41. https://doi.org/10.4137/CMED. S39427

40. Baktir AO, Dogan Y, Sarli B, et al. Relationship between 25-hydroxyvitamin D levels and the SYNTAX score in patients with acute coronary syndrome. Anatol J Cardiol. 2017;17(4):293-7.

41. Wang L, Song Y, Manson JE, et al. Circulating 25-hydroxyvitamin $\mathrm{D}$ and risk of cardiovascular disease: a metaanalysis of prospective studies. Circ Cardiovasc Qual Outcomes. 2012; 5(6): 819-29. https://doi.org/10.1161/ CIRCOUTCOMES.112.967604

42. Qi L, Ma W, Heianza Y, et al. Independent and synergistic associations of biomarkers of vitamin D status with risk of coronary heart disease. Arterioscler Thromb Vasc Biol. 2017; pii:ATVBAHA.117.309548.

43. Ng LL, Sandhu JK, Squire IB, et al. Vitamin D and prognosis in acute myocardial infarction. Int J Cardiol. 2013; 168(3): 2341-6. https://doi.org/10.1016/j.ijcard.2013.01.030

44. Porto CM, Silva VL, da Luz JSB, et al. Association between vitamin $\mathrm{D}$ deficiency and heart failure risk in the elderly. ESC Heart Fail. 2017; https://doi.org/10.1002/ehf2.12198.

45. Jiang WL, Gu HB, Zhang YF, et al. Vitamin D supplementation in the treatment of chronic heart failure: a meta-analysis of randomised controlled trials. Clin Cardiol. 2016;39(1):56-61. https://doi.org/10.1002/clc.22473

46. Amin A, Minaee S, Chitsazan M, et al. Can vitamin D supplementation improve the severity of congestive heart failure? Congest Heart Fail. 2013;19(4):E22-8. https://doi. org/10.1111/chf.12026

47. Boxer RS, Kenny AM, Schmotzer BJ, et al. A randomized controlled trial of high-dose vitamin D3 in patients with heart failure. JACC Heart Fail. 2013;1(1):84-90. https:// doi.org/10.1016/j.jchf.2012.11.003

48. Pekkanen MP, Ukkola O, Hedberg P, et al. Serum 25-hydroxyvitamin $\mathrm{D}$ is associated with major cardiovascularrisk factors and cardiac structure and function in patients with coronary artery disease. Nutrition, Metabolism \& Cardiovascular Diseases. 2015;xx: 1-8.

49. Marshall Brinkley D, Ali OM, ZalawadiyaSk, et al. Vitamin D and heart failure. Curr Heart Fail Rep. 2017; doi: 10.1007/s11897-017-0355-7. https://doi.org/10.1007/ s11897-017-0355-7

50. Ozcan OU, Gurlek A, Gursoy E, et al. Relation of vitamin $\mathrm{D}$ deficiency and new-onset atrial fibrillation among hypertensive patients. J Am SocHypertens. 2015; 9(4):30712. https://doi.org/10.1016/j.jash.2015.01.009

51. Vitezova A, Cartolano NS, Heeringa J, et al. Vitamin D and the Risk of Atrial Fibrillation - The Rotterdam Study. PLoS One. 2015; 10(5):e0125161. https://doi.org/10.1371/ journal.pone. 0125161

52. Demir M, Uyan U, Melek M. The Effects of Vitamin D Deficiency on Atrial Fibrillation. Clin Appl Thromb Hemost. 2014;20(1):98-103. https://doi. org/10.1177/1076029612453762

53. Thompson J, Nitiahpapand R, Bhatti P, et al. Vitamin D deficiency and atrial fibrillation. Int J Cardiol. 2015;184:15962. https://doi.org/10.1016/j.ijcard.2015.02.012

54. Gode S, Aksu T, Demirel A, et al. Effect of vitamin D deficiency on the development of postoperative atrial fibrillation in coronary artery bypass patients. J Cardiovasc Thorac Res. 2016;8(4):140-6. https://doi.org/10.15171/ jevtr.2016.29

55. Wang TJ, Pencina MJ, Booth SL, et al. Vitamin D deficiency and risk of cardiovascular disease. Circulation. 2008;117(4):503-11. https://doi.org/10.1161/ CIRCULATIONAHA.107.706127

56. Gaksch M, Jorde R, Grimnes G, et al. Vitamin D and mortality: Individual participant data meta-analysis of standardized 25-hydroxyvitamin D in 26916 individuals from a European consortium. PLoS One. 2017;12(2):e0170791. https://doi.org/10.1371/journal. pone. 0170791

57. D'Amore C,Marsico F, Parente A, et al.Vitamin D deficiency and clinical outcome in patients with chronic heart failure: A review. Nutr Metab Cardiovasc Dis. 2017;27(10):837-49. https://doi.org/10.1016/j.numecd.2017.07.009

58. Veloudi P, Jones G, Sharman E. Effectiveness of vitamin D supplementation for cardiovascular health outcomes. Pulse (Basel). 2017;4(4):193-207. https://doi. org $/ 10.1159 / 000452742$

59. Butlin M, Avolio AP. Cardiovascular effects of long-term vitamin D supplementation: summarised by many but 
studied by few. Pulse (Basel). 2017;4(4):172-4. https://doi. org/10.1159/000452939

60. Ford JA, MacLennan GS, Avenell A, et al. Cardiovascular disease and vitamin $\mathrm{D}$ supplementation: trial analysis, systematic review, and meta-analysis. Am J Clin Nutr. 2014;100(3):746-55.

Cite this article as: Hridaya Bibhu Ghimire, Chandra Mani Adhikari. Association of vitamin D and cardiovascular health. Nepalese Heart Journal 2018; 15(1): 17-21.

http://dx.doi.org/10.3126/njh.v15i1.19706
61. Lugg ST, Howells PA, Thickett DR. Optimal vitamin D supplementation levels for cardiovascular disease protection. Dis Markers. 2015;864370. https://doi. org/10.1155/2015/864370 